\title{
APPLICATION OF THE ACETOLACTATE DECARBOXYLASE FROM LACTOBACILLUS CASEI FOR ACCELERATED MATURATION OF BEER
}

by

\author{
SVEN ERIK GODTFREDSEN, ANNE MUNK RASMUSSEN and MARTIN OTTESEN
}

Department of Chemistry, Carlsberg Laboratory, Gamle Carlsberg Vej 10, DK-2500 Copenhagen Valby

and

\section{THOMAS MATHIASEN and BENT AHRENST-LARSEN}

Department of Brewing Chemistry, Carlsberg Research Laboratory, Gamle Carlsbergvej 10, DK-2500 Copenhagen Valby

Keywords: Diacetyl, acetolactic acid, lactic acid bacteria, zinc, 2,3-pentanedione, $\alpha$-aceto- $\alpha$-hydroxybutyrate, fermentation.

The acetolactate decarboxylase produced by Lactobacillus casei DSM 2547 has been tested as an aid for accelerated removal of the diacetyl precursor acetolactic acid from beer. Addition of the enzyme to freshly fermented beer has been shown to effect efficient removal of the diacetyl precursor while addition of the decarboxylase to wort prior to pitching was found to lead to subsequent inactivation of the enzyme during the fermentation. It has been shown that zinc is a component of the acetolactate decarboxylase system, and that growing yeast cells remove the zinc ions.

\section{INTRODUCTION}

Acetolactate decarboxylases are attractive possible means for effecting selective removal of acetolactate and hydroxybutyrate from beer and thus for accelerated maturation of beer: Treatment of freshly fermented beer for 24 hours at 10 ${ }^{\circ} \mathrm{C}$ with preparations of the acetolactate decarboxylase produced by Enterobacter aerogenes strain 1033 has been found to provide beer of a satisfactory quality (5). Addition of acetolactate decarboxylases isolated from species of Bacillus licheniformis to fermenting wort has also proven the feasibility of removing acetolactate during the main fermentation of beer (7).

Among the various bacterial species found to generate acetolactate decarboxylase activity (6) some are, a priori, quite promising sources of decarboxylases for application in industrial brewing. Species of Bacillus licheniformis found to generate the decarboxylase are thus widely applied for production of various food-grade enzymes and a large number of lactic acid

Abbreviations: DSM = Deutsche Sammlung von Microorganismen, EBC = European Brewery Convention. 
Table I.

Concentration of vicinal diketones and their precursors in 25 liter portions of beer matured for 22 hours at $7^{\circ} \mathrm{C}$ in the presence of the acetolactate decarboxylase from Lactobacillus casei in quantities corresponding to $41 \mathrm{kU} /$ litre and in a reference brew matured similarly in the absence of enzyme.

\begin{tabular}{|c|c|c|c|c|}
\hline $\begin{array}{l}\text { Acetolactate decarboxylase } \\
\qquad \mathrm{KU} \times \mathrm{I}^{-1}\end{array}$ & $\begin{array}{l}\text { Diacetyl } \\
\text { ppm }\end{array}$ & $\begin{array}{l}\text { Acetolactate } \\
\text { ppm }\end{array}$ & $\begin{array}{l}\text { 2,3-Pentanedione } \\
\text { ppm }\end{array}$ & $\begin{array}{l}\text { Hydroxybutyrate } \\
\text { ppm }\end{array}$ \\
\hline 0 & 0.18 & 0.95 & 0.12 & 0.59 \\
\hline 41 & 0.01 & 0.06 & 0.01 & 0.03 \\
\hline
\end{tabular}

bacteria, also found to produce acetolactate decarboxylases (8), have a long and well established history of use in the dairy industry, for example for aroma generation in cheese or for preparation of fermented milk products. These bacteria, which include species of Lactobacillaceae and Streptococcaceae, are, therefore, widely accepted for preparation of food products and, accordingly, attractive sources of enzymes for use in industrial production of beer.

Acetolactate decarboxylases to be applied in brewing should, preferably, fulfil a number of criteria. It is clearly desirable that the enzyme can be readily solubilized and, also, that the enzyme possesses a good activity and stability at the low $\mathrm{pH}$ prevailing in beer. Moreover, preparations of the enzyme amenable for production on an industrial scale should be devoid of any activity affecting constituents of beer other than acetolactate and acetohydroxybutyrate and, finally, the enzyme should possess a good stability and activity when applied in actual brewing processes during maturation as well as during fermentation.

In the course of a screening for acetolactate decarboxylases among lactic acid bacteria it was found that some species such as Streptococcus diacetylactis generate acetolactate decarboxylase activity which cannot be solubilized while other species as e. g. Lactobacillus casei generate a readily solubilized acetolactate decarboxylase which exhibits a good stability and activity at the $\mathrm{pH}$ of beer and which is amenable for large scale production (8).

In the present work, this enzyme has been tested in the brewing process and found suitable for beer maturation when added to maturing beer in spite of the fact that the enzyme was inactivated in the course of the maturation period. When tested in fermenting wort, the stability of the enzyme was, however, found insufficient to reduce the contents of acetolactate and hydroxybutyrate to acceptable levels at the end of the fermentation and the enzyme was, therefore, judged to be unsuitable for application during the main fermentation of beer.

\section{MATERIALS AND METHODS}

Acetolactate decarboxylase activity was assayed in acetate buffer at pH 5.0 as described elsewhere (5). Samples of beer assayed were freed from yeast cells by centrifugation prior to analysis.

Samples of acetolactate decarboxylase tested were isolated from Lactobacillus casẹ DSM 2547 and, prior to use, purified to a specific activity of approximately $1000 \mathrm{U} / \mathrm{mg}$ by methods described elsewhere (8).

Vicinal diketones and their precursors were measured by gas-liquid chromatography as described by HAUKELI and LIE (9).

Fermentation of $10.7 \%$ Plato wort pitched with Saccharomyces carlsbergensis strain $F$ were carried out in 21 EBC tubes (3) or in 30 litre cylindrical fermentation vessels at $10^{\circ} \mathrm{C}(1)$. Maturation of beer prepared in EBC tubes was carried out in 2-litre flasks after transfer of the beer under a carbon dioxide atmosphere.

Zinc analyses were carried out by atomic absorption spectrophotometry according to the EBC method (2).

\section{RESULTS AND DISCUSSION}

The contents of free diacetyl, acetolactate, 2,3-pentanedione, and acetohydroxybutyrate in freshly fermented beer and in the same beer 
matured for 22 hours at $7{ }^{\circ} \mathrm{C}$ after addition of the acetolactate decarboxylase from Lactobacillus casei DSM 2547 in quantities corresponding to $41 \mathrm{kU} / \mathrm{litre}$ of beer are shown in Table I. Addition of the acetolactate decarboxylase preparation served to reduce the content of the vicinal diketones and their precursors to below their taste thresholds in the course of the short maturation time whereas the content of the vicinal diketones and their precursors in untreated beer is only marginally reduced. Accordingly, taste panel evaluations revealed a potent diacetyl flavour in the reference brew while no such flavour was noticed in the test brew which was judged to be of a satisfactory quality.

On the basis of this evaluation, it appeared that the enzymatic removal of acetolactate and acetohydroxybutyrate had taken place with no effect on other properties of the beer and, consequently, that the applied preparation of acetolactate decarboxylase from Lactobacillus casei was well suited as a maturation aid when added to beer after the main fermentation. Since, however, from a practical and economical point of view, it is desirable to add the maturation aid not after but before the main fermentation, the suitability of the acetolactate decarboxylase preparation was tested in this respect also by adding the maturation aid to wort prior to pitching. Contrary to expectations based on the demonstrated stability of the enzyme not only at the $\mathrm{pH}$ of fermenting wort but also in green beer freed from yeast (8) it was found that the acetolactate decarboxylase was rapidly inactivated in fermenting wort. This is shown in Figure 1 which indicates the decay of enzymatic activity in a batch of fermenting wort containing the acetolactate decarboxylase in a quantity corresponding to $52 \mathrm{kU}$ per litre at the beginning of the fermentation. It is noteworthy that the enzymatic activity is almost entirely quenched at the second day of the fermentation i. e. at the time when formation of acetolactate is usually initiated and the yeast is proliferating rapidly.

The basis for the observed inactivation can be deduced from Figure 2 which illustrates the stability of the acetolactate decarboxylase from Lactobacillus casei when incubated at $5{ }^{\circ} \mathrm{C}$ in buffer solutions with or without yeast cells from freshly fermented beer and various divalent

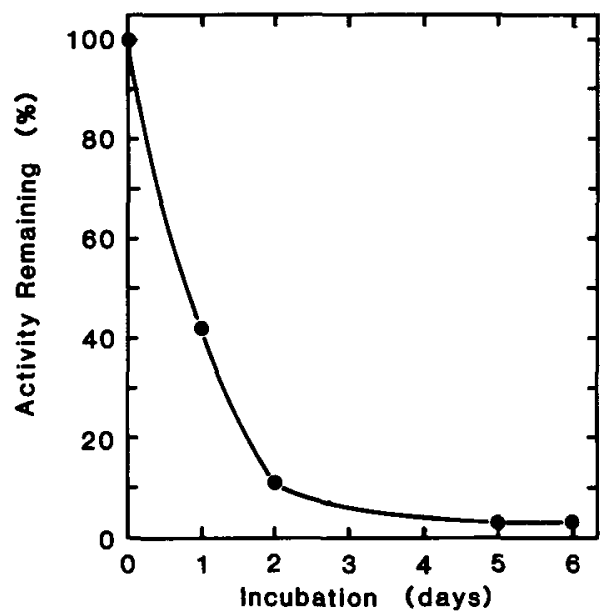

Figure 1. Decay of acetolactate decarboxylase activity in fermenting wort enriched with $52{\mathrm{U} \times \mathrm{ml}^{-1}}^{-1}$ of the decarboxylase prior to pitching.

metal ions. It is seen that the enzyme is almost completely inactivated by the yeast cells except when zinc ions are added to the yeast suspension. Since no inactivation was observed during dialysis against freshly fermented beer freed from yeast cells or even freshly fermented beer containing homogenized yeast cells, the observed inactivation by living yeast cells is most probably due to yeast induced zinc depletion of

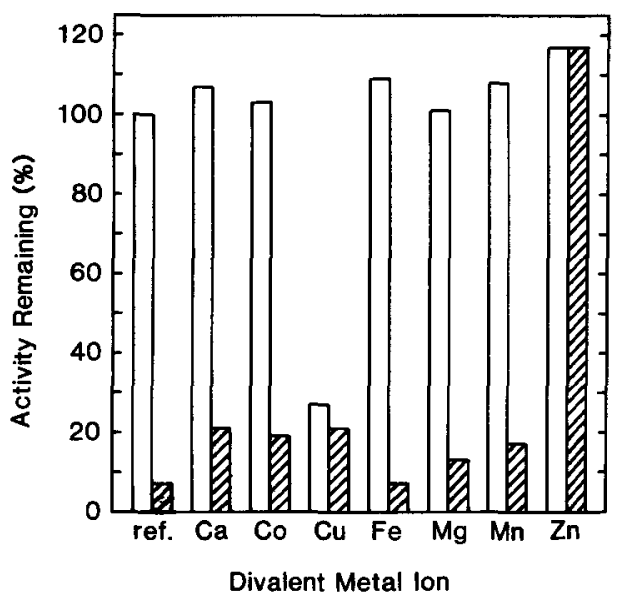

Figure 2. Activity of acetolactate decarboxylase retained after incubation for 18 hours at $5^{\circ} \mathrm{C}$ in $20 \mathrm{~mm}$ acetate buffer at pH 4.2 devoid of (blank columns) or containing active yeast cells (crossed columns) besides $1 \mathrm{ppm}$ of the divalent metal ions indicated. The initial

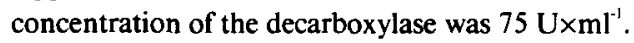


Table II.

Stability of the acetolactate decarboxylase from Lactobacillus casei in fermenting wort enriched with zinc ions and $10 \mathrm{kU} \times l^{-1}$ of decarboxylase activity.

\begin{tabular}{|c|c|c|c|c|c|c|c|}
\hline \multicolumn{5}{|c|}{ Remaining enzymatic activity (\%) } & \multirow{3}{*}{$\begin{array}{l}\text { Zinc added } \\
\text { to wort } \\
\text { ppm }\end{array}$} & \multirow{3}{*}{$\begin{array}{l}\text { Zinc detected } \\
\text { in beer } \\
\text { ppm }\end{array}$} & \multirow{3}{*}{$\begin{array}{l}\text { Acetolactate plus } \\
\text { diacetyl in beer } \\
\text { ppm }\end{array}$} \\
\hline \multicolumn{5}{|c|}{ Fermentation time (days) } & & & \\
\hline 0 & 1 & 2 & 5 & 6 & & & \\
\hline 100 & 56 & 34 & 3 & 5 & $0.0^{5}$ & 0.0 & 1.32 \\
\hline 100 & 60 & 32 & 6 & 4 & 0.5 & 0.00 & 1.32 \\
\hline 100 & 62 & 31 & 6 & 5 & 1.0 & 0.00 & 1.30 \\
\hline 100 & 63 & 35 & 6 & 5 & 5.0 & 0.01 & 1.15 \\
\hline 100 & 100 & 95 & 84 & 100 & 25.0 & 5.50 & $0.04^{\S}$ \\
\hline
\end{tabular}

the acetolactate decarboxylase. This mechanism of inactivation is in accordance with the zinc dependence of the acetolactate decarboxylase (A. M. RASMUSSEN et al. , unpublished results) and the requirement of brewer's yeast for zinc (4, 10). The inactivation is thus readily explained by the presence of a zinc transport system in the cell membrane of the yeast cell with an affinity for the metal ion of sufficient strength to compete with the acetolactate decarboxylase for zinc ions in fermenting wort.

In order to investigate the possibilities for obviating inactivation of the acetolactate decarboxylase in fermenting wort the stability of the enzyme was monitored during a series of fermentations of wort containing the decarboxylase and varying concentrations of zinc ions. The results summarized in Table II indicate that a rapid inactivation of the decarboxylase takes place in the presence of fermenting yeast cells unless rather large quantities of zinc are added to the wort: addition of $0.5,1.0$, and $5.0 \mathrm{ppm}$ of the metal ion was thus found insufficient to stabilize the acetolactate decarboxylase activity which, accordingly, exerted only a minor influence on the content of acetolactate detected in the final beer while addition of $25 \mathrm{ppm}$ of zinc ions to fermenting wort served to stabilize the acetolactate decarboxylase and thus permitted the desired enzymatic reduction of the acetolactate level in the finished beer. These findings are in accord with the obser- vation that the yeast cells depleted the beer completely for zincs ions unless $25 \mathrm{ppm}$ of the metal ion was added to the wort, c. f. Table II.

The observation that large quantities of zinc ions are required to stabilize the acetolactate decarboxylase in fermenting wort is in contrast with findings regarding the quantity of the metal required to stabilize the decarboxylase in fermented beer. This is apparent from Figure 3 which relates to the stability of the acetolactate decarboxylase during incubation with green beer enriched with various quantities of zinc ions. It can be seen that a stabilizing effect can be

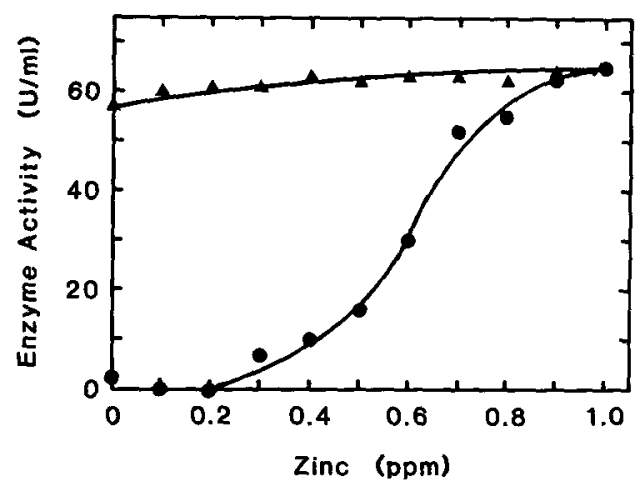

Figure 3. Activity of acetolactate decarboxylase from Lactobacillus casei after incubation for 24 hours at $5^{\circ} \mathrm{C}$ in green beer enriched with 1 ppm zinc and containing ( $-\boldsymbol{Q})$ or freed $(\boldsymbol{\Delta}-\boldsymbol{\Delta})$ from yeast cells. The initial concentration of the decarboxylase was 60 $\mathrm{U} \times \mathrm{ml}^{-1}$. 
Table III.

Concentration of vicinal diketones and their precursors in a reference brew and in beer matured for 48 hours at 5 ${ }^{\circ} \mathrm{C}$ in the presence of the acetolactate decarboxylase from Lactobacillus casei in concentrations corresponding to 6 and $11 \mathrm{kU}$ per litre of beer.

\begin{tabular}{ccccc}
\hline $\begin{array}{c}\text { Acetolactate decarboxylase } \\
\mathrm{kUx}^{-1}\end{array}$ & $\begin{array}{c}\text { Diacetyl } \\
\mathrm{ppm}\end{array}$ & $\begin{array}{c}\text { Acetolactate } \\
\mathrm{ppm}\end{array}$ & $\begin{array}{c}2,3-\text { Pentanedione } \\
\mathrm{ppm}\end{array}$ & $\begin{array}{c}\text { Hydroxybutyrate } \\
\mathrm{ppm}\end{array}$ \\
\hline 0 & 0.12 & 0.72 & 0.07 & 0.52 \\
6 & 0.05 & 0.02 & 0.05 & 0.08 \\
11 & 0.05 & 0.03 & 0.03 & 0.02 \\
\hline
\end{tabular}

detected after addition of only $0.3 \mathrm{ppm}$ of zinc ions while complete stabilization is achieved by addition of $1 \mathrm{ppm}$ of zinc ions to the green beer.

Presumably, the striking difference in the stabilizing effect of zinc added during fermentation and during maturation reflects concomitant activation of the zinc transport system and the metabolic activity of the yeast cell. It was assumed, therefore, that it would be possible to effect conversion of acetolactate after the main fermentation by adding only small quantities of the acetolactate decarboxylase to the green beer, in particular if addition of the enzyme was carried out under careful exclusion of oxygen and thus without unduly activating the metabolic activity of the small quantities of yeast present in the maturing beer (9). From Table III it is apparent that it is indeed possible to effect the desired conversion of acetolactate in green beer in the course of $48 \mathrm{~h}$ at $5^{\circ} \mathrm{C}$ by addition of only $6 \mathrm{kU}$ of acetolactate decarboxylase per litre of beer under careful exclusion of air and without enriching the beer with zinc in spite of the fact that the enzyme was found to be entirely quenched in the course of the 48 hours even under these conditions.

The specific activity of the purified acetolactate decarboxylase from Lactobacillus casei is unusually high (A. M. RASMUSSEN et al. , unpublished results) compared to the only other acetolactate decarboxylase properly characterised so far (11). The weight of pure enzyme required to effect removal of acetolactate from green beer under optimal conditions is, therefore, very low. This suggests that the cost of the enzyme required for beer maturation will also be low. From this point of view the acetolactate decarboxylase from Lactobacillus casei is very attractive as an aid for accelerating maturation of beer. Taking into account, however, that use of the enzyme during the main fermentation of beer requires addition of zinc to the wort in quantities outside the scope of reality and, furthermore, that successful application of the maturation aid in green beer in many cases may present practical problems related to the actual process design it appears, all in all, that the practical utility of the decarboxylase from Lactobacillus casei, however desirable from the point of view of safety and selectivity of the enzyme preparations, is rather limited. The experiments carried out with the enzyme from Lactobacillus casei have, however, substantiated the feasibility of enzymatic beer maturation which, accordingly, may well be realized with acetolactate decarboxylases from other strains of bacteria free of limitations posed by the specific properties of the decarboxylase from Lactobacillus casei.

\section{ACKNOWLEDGEMENTS}

The authors are indebted to A. OLSEN and A. SCHOUBOE for performing GLC measurements. Also acknowledged is technical assistance by $\mathrm{K}$. ThornberG, G. Dalkov, N. Gammelby, and B. STADEL.

\section{REFERENCES}

1. Ahrenst-LarSen, B.\& K. ERdal: Antocyanogenfree Barley - a Key to natural Prevention of Beer Haze. Proceedings of the European Brewery Convention, Berlin. 631-644 (1979)

2. Analytica-EBC. Schweizer Brauerei-Rundschau, 1975. International Method 7.25.

3. EBC Analytica Microbiologica. J. Inst. Brew. 83, $117-118(1977)$ 
4. Densky, H., P.J. Gray \& A. Buday: Further Studies on the Detection of Zinc and its Effect on Various Yeasts. American Society of Brewing Chemists, Proceedings, 93-100 (1966)

5. GodTfREDSEN, S.E. \& M. OtTESEN: Maturation of Beer with $\alpha$-Acetolactate Decarboxylase. Carlsberg Res. Commun. 47, 93-102 (1982)

6. GodtFredsen, S.E., H. Lorck, \& P. Sigsgaard: On the Occurence of $a$-Acetolactate Decarboxylases among Microorganisms. Carlsberg Res.Commun.48, 239-47 (1983)

7. GodtFredsen. S.E., M. OtTesen, P. SigsgaARD, K. ERdal, T. Mathiasen, \& B. Ahrenst-LarSEN: Use of $\alpha$-Acetolactate Decarboxylase for Accelerated Maturation of Beer. Proceedings of the European Brewery Convention Congress,London.161$168(1983)$
8. Godtfredsen, S.E., A.M. Rasmussen, M. OtteSEN, P. RAFN \& N. PeITERSEN: Occurrence of Acetolactate Decarboxylases among Lactic acid Bacteria and their Utilization for Beer Maturation. In press. European J. Microbiol. Biotechn. (1984)

9. HAUKELI, A.D. \& S. LiE: The Influence of $\alpha$-Acetohydroxy Acids on the Determination of Vicinal Diketones in Beer and during Fermentation. $\mathrm{J}$. Inst.Brew. 77, 538-543 (1971)

10. LIE, S. \& T. JACOBSEN: The Absorbtion of Zinc by Brewer's Yeast. Proceedings of the European Brewery Convention Congress, London. 145-151 (1983)

11. LøKEN, J.P. \& F.C. STøRMER: Acetolactate Decarboxylase from Aerobacter aerogenes. Purification and Properties. Eur. J. Biochem. 14, 133-137 (1970) 